\title{
DECLARAÇ Ã O
}

Eu, Isabella Corrêa Brandão, RG 24.596.549-6, graduada em Letras com Habilitação em Espanhol, declaro ter realizado a análise e correção ortográfica do artigo tendo como título: "A classe nos une, o gênero nos divide: imbricações entre patriarcado e capitalismo", realizado pela acadêmica Ana Carolina Brandão Vazquez da Universidade Federal do Rio de Janeiro (UFRJ).

Por ser verdade firmamos o presente.

Rio de Janeiro, 10 de julho de 2018.

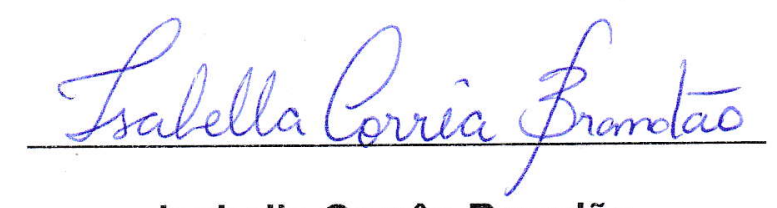

Isabella Corrêa Brandão

Licenciada em Letras - Português/Espanhol 